$\begin{gathered}\text { Науковий вісник Нлту України } \\ \text { Scientific Bulletin of UNFU } \\ \text { https://nv.nltu.edu.ua }\end{gathered}$
$\begin{gathered}\text { https://doi.org/10.15421/40290222 } \\ \text { Article received 01.03.2019 p. } \\ \text { Article accepted 28.03.2019 p. } \\ \text { УДSN 1994-7836 (print) } \\ \text { ISSN 2519-2477 (online) }\end{gathered}$

Е. М. Гуліда 1 , О. М. Коваль' ${ }^{2}$ І. В. Паснак ${ }^{1}$ В. В. Шарий ${ }^{1}$

${ }^{1}$ Львівський державний університет безпеки життедіяльності, м. Львів, Украйна

${ }^{2}$ ТзОВ Компанія "Всесвіт Комфорту" м. Львів, Украӥна

\title{
АНАЛІЗ СУЧАСНОГО СТАНУ ЗАБЕЗПЕЧЕННЯ ПОЖЕЖНОЇ БЕЗПЕКИ ПРОМИСЛОВИХ БУДІВЕЛЬ ТА СКЛАДІВ
}

\begin{abstract}
Проаналізовано світовий досвід у царині забезпечення пожежної безпеки промислових будівель та складів, що головно базується на огляді публікацій за останні 5 років, зокрема і тих, що індексуються в наукометричній базі Scopus. Актуальним завданням у царині пожежної безпеки є розвиток уявлення про можливі перспективні напрями розвитку систем протипожежного захисту промислових будівель та складів, що має базуватися на грунтовному аналізі світового досвіду у цій площині. Проаналізовано вплив чинників пожежної безпеки підприємств нафтохімічної промисловості, підземного зберігання дизельного палива, складів текстильної промисловості та складів тютюну з точки зору аспектів свідомості та обізнаності персоналу в царині пожежної безпеки, протипожежних об'єктів (об'єктових пожежно-рятувальних частин, добровільних пожежних команд тощо), управління пожежною безпекою та технічного забезпечення, а також наведено причинно-наслідковий аналіз цієї системи. Встановлено, що забезпечення пожежної безпеки підприємств грунтується на ефективному функціонуванні систем протипожежного захисту, а також принципах раннього виявлення пожеж шляхом застосування сучасних систем пожежної сигналізації. З'ясовано, що перспективи розвитку в окресленій проблематиці мають базуватися на застосуванні сучасних технологій, досконалості нормативно-технічної бази, а також застосуванні новітніх підходів до організації системи протипожежного захисту промислових будівель та складів.
\end{abstract}

Ключові слова: промислове підприємство; пожежна безпека; системи протипожежного захисту; профілактика пожеж; перспективи розвитку.

Вступ. Відомо, що передумовою для розроблення будь-яких заходів з удосконалення певного процесу $є$ грунтовний аналіз сучасного стану розглядуваного питання. Для цього потрібно здійснити огляд сучасного стану забезпечення пожежної безпеки на підприємствах промисловості, де ризик виникнення пожеж є доволі високим.

Згідно $з$ даними (DBN V.2.5-56:2015, 2014), до систем протипожежного захисту належать:

- системи пожежної сигналізації;

- автоматичні системи пожежогасіння;

- автономні системи пожежогасіння локального застосування;

- системи оповіщування про пожежу та управління евакуюванням людей;

- системи протидимного захисту;

- системи централізованого пожежного спостерігання;

- системи диспетчеризації.

Також сюди належать (Hulida \& Koval, 2017): блискавкозахист; ліфти пожежні; протипожежні двері, клапани, ворота, завіси (екрани) тощо. Промислові під- приємства мають бути забезпечені протипожежним водопостачанням у вигляді внутрішніх пожежних кранкомплектів, пожежних гідрантів або пожежних водоймищ.

Необхідність постійного удосконалення систем протипожежного захисту промислових будівель та складів зумовлена великою пожежною навантагою таких об'єктів, а також високою лінійною швидкістю розповсюдження пожежі (Kropyvnytskyi, 2016). Тому, зважаючи на викладене, актуальним завданням у царині пожежної безпеки є розвиток уявлення про можливі перспективні напрямки розвитку систем протипожежного захисту промислових будівель та складів, що має базуватися на грунтовному аналізі світового досвіду у цій площині.

Мета роботи - проаналізувати світовий досвід у царині забезпечення пожежної безпеки промислових будівель та складів і виокремити перспективні напрями розвитку в цій галузі.

Викладення основного матеріалу. Яскравим свід-

Інформація про авторів:

Гуліда Едуард Миколайович, д-р техн. наук, професор, завідувач кафедри пожежної тактики та аварійно-рятувальних робіт. Email: gulida24@meta.ua; https://orcid.org/0000-0002-3881-7206

Коваль Олександр Мирославович, д-р техн. наук, фінансовий директор. Email: 80koval@gmail.com; https://orcid.org/0000-0002-6208-6482

Паснак Іван Васильович, канд. техн. наук, доцент, заступник начальника інституту з навчально-наукової роботи навчальнонаукового інституту пожежної та техногенної безпеки. Email: van-pas@ukr.net; https://orcid.org/0000-0002-8405-4625

Шарий Володимир Володимирович, ад'юнкт, кафедра пожежної тактики та аварійно-рятувальних робіт. Email: vollost@gmail.com; https://orcid.org/0000-0001-8746-2184

Цитування за ДстУ: Гуліда Е. М., Коваль О. М., Паснак І. В., Шарий В. В. Аналіз сучасного стану забезпечення пожежної безпеки промислових будівель та складів. Науковий вісник НлТУ України. 2019, т. 29, № 2. С. 109-111.

Citation APA: Hulida, E. M., Koval, O. M., Pasnak, I. V., \& Sharyi, V. V. (2019). Analysis of the modern state of providing fire safety in industrial buildings and storages. Scientific Bulletin of UNFU, 29(2), 109-111. https://doi.org/10.15421/40290222 
ченням окресленої проблематики є графічна залежність (Pasnak, et al., 2016), наведена на рис. 1.

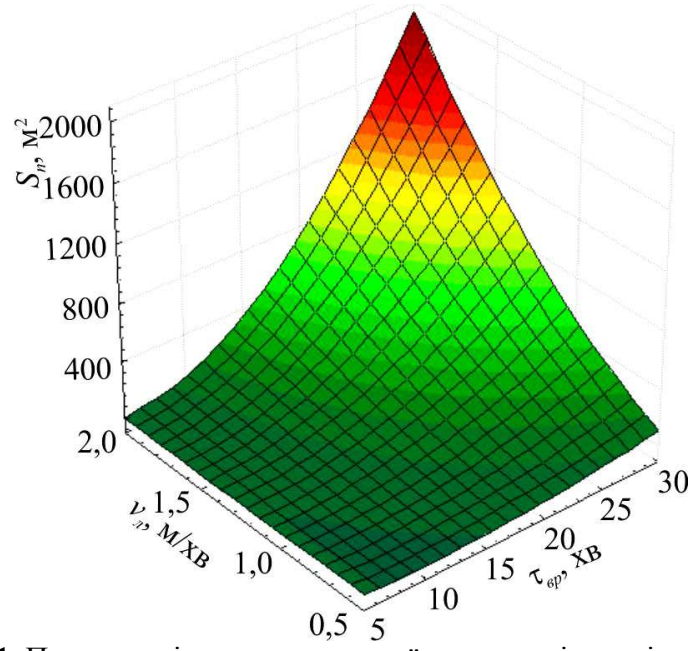

Рис. 1. Поверхня відгуку теоретичної залежності площі пожежі

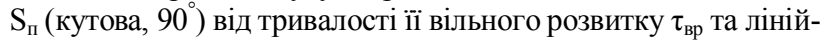
ної швидкості розповсюдження пожежі $\mathrm{V}_{\text {л }}$ (Pasnak, et al., 2016)

3 рис. 1 можна зробити висновок, що, наприклад, у столярному цеху за 20 хв вільного розвитку пожежа охопить площу близько $700 \mathrm{~m}^{2}$. Це, своєю чергою, зумовлює необхідність наявності ефективної системи протипожежного захисту для мінімізації можливих збитків, що може завдати пожежа.

У роботі (Zhang, Zhang \& Qian, 2018) наведено схему системи протипожежного захисту підприємства нафтохімічної промисловості (рис. 2).

\begin{tabular}{|l|l|l|l|l|}
\multicolumn{2}{|c|}{$\begin{array}{c}\text { Система протипожежного захисту підприємства } \\
\text { нафтохімічної промисловості }\end{array}$} \\
\begin{tabular}{|c|c|c|c|} 
Свідомість та \\
обізнаність \\
персоналу
\end{tabular} & $\begin{array}{c}\text { Протипожежні } \\
\text { об'єкти }\end{array}$ & $\begin{array}{c}\text { Управління } \\
\text { пожежною } \\
\text { безпекою }\end{array}$ & $\begin{array}{c}\text { Технічне } \\
\text { забезпечення }\end{array}$ \\
\hline
\end{tabular}

Рис. 2. Схема системи протипожежного захисту підприємства нафтохімічної промисловості (Zhang, Zhang, \& Qian, 2018)

Зокрема, у роботі (Zhang, Zhang \& Qian, 2018) проаналізовано вплив чинників пожежної безпеки підприємства нафтохімічної промисловості з точки зору аспектів свідомості та обізнаності персоналу в царині пожежної безпеки, протипожежних об'єктів (об'єктових пожежно-рятувальних частин, добровільних пожежних команд тощо), управління пожежною безпекою та технічного забезпечення, а також наведено причинно-наслідковий аналіз цієї системи. На основі цього побудовано математичну модель системи протипожежного захисту такого підприємства. Результати досліджень математичної моделі (Zhang, Zhang \& Qian, 2018) дали змогу виявити причинно-наслідковий зв'язок як між чинниками пожежної безпеки, так і між чинниками та рівнями системи протипожежного захисту, що своєю чергою, дало змогу динамічно прогнозувати рівень забезпечення пожежної безпеки.

Результати експериментальних досліджень щодо раннього виявлення пожежі в підземних сховищах дизельного пального, що базуються на дослідженні ефективності застосування пожежних сповіщувачів різного типу (вогню, диму, СО), наведено в (Yuan, et al., 2018). Зокрема, для зменшення ризику, пов'язаного зі зберіганням і перенесенням великої кількості дизельного пального в постійні сховища підземних шахт, проведе- но експериментальне дослідження часу спрацювання різних сповіщувачів для раннього виявлення пожеж дизельного пального в зоні зберігання. Проаналізовано час реакції для сповіщувачів різного типу та встановлено, що сповіщувачі полум'я і сповіщувачі диму призвели до зменшення часу спрацювання у більшості дослідів порівняно зі сповіщувачами СО. На основі результатів експериментальних досліджень визначено відповідні місця розташування сповіщувачів для раннього виявлення пожежі в зоні зберігання дизельного пального.

Проаналізувавши роботи (Zhang, Zhang \& Qian, 2018; Yuan, et al., 2018), бачимо, що забезпечення пожежної безпеки підприємств нафтохімічної промисловості базується на ефективному функціонуванні систем протипожежного захисту, а також принципах раннього виявлення пожеж шляхом застосування сучасних систем пожежної сигналізації. Цей висновок підтверджують результати, отримані в роботі (Festag, 2016). Тут вкотре наголошено, що якомога швидше виявлення пожежі дає змогу зменшити збитки від неї. 3 цією метою описується важливість встановлення пожежної сигналізації. У статті (Festag, 2016) проаналізовано процес хибного спрацьовування протипожежної сигналізації в Нiмеччині. Високочутливі елементи в пожежних сповіщувачах дають змогу ідентифікувати пожежі на ранній стадії, але це також робить їх чутливим до хибних спрацювань.

Улаштування систем пожежної сигналізації має закладатися ще на стадії проектування того чи іншого об'єкту. Зокрема, в роботі (Maluk, Woodrow \& Torero, 2017) наголошено на важливості врахування забезпечення пожежної безпеки ще на стадії проектування будівель та споруд.

Аналіз системи пожежної безпеки підприємств зберігання небезпечних хімічних речовин наведено в (Zhang, 2018). Для оцінювання рівня пожежної безпеки такого підприємства в згаданій роботі застосовано ідентифікацію джерела небезпеки, моделі пожежної та вибухової ситуації, процесу аналітичної ієрархії та оцінки пожежної небезпеки на певному інтервалі. Стаття (Zhang, 2018) надає наукову основу для оцінки ризику пожежної небезпеки складів хімічних речовин, а також підгрунтя для встановлення якісної системи контролю безпеки для ефективного управління пожежною безпекою.

Пожежні ризики на складах текстильної промисловості проаналізовано в (Ма, 2014). Автор наголошує, що масштабні пожежі виникають через низький рівень систем протипожежного захисту. Зокрема наголошено на комплексності підходу до питань забезпечення пожежної безпеки: дотримання відповідних норм та правил, забезпеченості підприємств необхідними системами протипожежного захисту тощо.

Досвід забезпечення пожежної безпеки на складах тютюну та тютюнових виробів описано в (Zhang \& Huang, 2013). Тут увагу зосереджено на дотриманні відстаней протипожежних розривів та ефективній роботі систем пожежної сигналізації. На таких фабриках має бути достатнє забезпечення протипожежним водопостачанням, а також влаштовані автоматичні системи пожежогасіння.

Також важливим є аспект нормативного регулювання у царині пожежної безпеки. У роботі (Rodrigues, et al., 2017) показано особливості нормативного регулювання пожежної безпеки в Бразилії. Зокрема, з'ясовано, 
що невідповідність норм та правил пожежної безпеки у різних штатах великої країни може призвести до певних проблем. У роботі проаналізовано загальні аспекти вимог до систем протипожежного захисту в різних штатах та наголошено на необхідності створення загальнодержавних норм.

У роботі (Olawoyin, 2018) розглянуто перспективи застосування нанотехнологій у царині пожежної безпеки. Зокрема, вказано на можливість їх застосування для підвищення вогнестійкості матеріалів. У цьому дослідженні додатково розглянуто деякі недоліки з використанням нанотехнологій. Наведено можливість негативного впливу деяких чинників нанотехнологій на організм людини. Однак, автор стверджує, що якщо нанотехнологія перевірена та застосовується належно, то вона може стати майбутнім у царині пожежної безпеки.

У випадку, якщо пожежа все-таки виникла на промисловому підприємстві, то поряд із швидкою евакуацією людей та матеріальних цінностей необхідно здійснювати ефективне управління діяльністю пожежно-рятувальних підрозділів та добровільних пожежних команд для ефективної ліквідації пожежі (Pasnak, Prydatko \& Gavrilyk, 2016).

\section{Висновки:}

1. Проаналізовано результати останніх досліджень у царині забезпечення пожежної безпеки промислових будівель та складів. Встановлено, що забезпечення пожежної безпеки підприємств базується на ефективному функціонуванні систем протипожежного захисту, а також принципах раннього виявлення пожеж шляхом застосування сучасних систем пожежної сигналізації.

2. Перспективи розвитку в окресленій проблематиці мають базуватися на застосуванні сучасних методів виявлення пожежі та досконалості нормативно-технічної бази, а також використанні новітніх підходів до організації системи протипожежного захисту промислових будівель і складів.

\section{Перелік використаних джерел}

DBN V.2.5-56:2015. (2014). Systemy protypozhezhnoho zakhystu. Ministerstvo rehionalnoho rozvytku, budivnytstva ta zhytlovo-komunalnoho hospodarstva Ukrainy. Kyiv, 185 p. [In Ukrainian].
Festag, S. (2016). False alarm ratio of fire detection and fire alarm systems in Germany - a meta analysis. Fire Safety Journal, 79, 119-126. https://doi.org/10.1016/j.firesaf.2015.11.010

Hulida, E. M., \& Koval, O. M. (2017). Zabezpechennia pozhezhnoi bezpeky ta likvidatsiia pozhezh na derevoobrobnykh pidpryiemstvakh. Lviv: PAIS, 272 p. [In Ukrainian].

Kropyvnytskyi, V. S. (Ed.). (2016). Dovidnyk kerivnyka hasinnia pozhezhi. Kyiv: TOV "Litera-Druk", 320 p. [In Ukrainian].

Ma, J. Y. (2014). Analysis on the fire risk existing in the storage of textile materials and textile goods. Procedia engineering, 71, 271275. https://doi.org/10.1016/j.proeng.2014.04.039

Maluk, C., Woodrow, M., \& Torero, J. L. (2017). The potential of integrating fire safety in modern building design. Fire Safety Journal, 88, 104-112. https://doi.org/10.1016/j.firesaf.2016.12.006

Olawoyin, R. (2018). Nanotechnology: the future of fire safety. Safety science, 110, 214-221. https://doi.org/10.1016/j.ssci.2018.08.016

Pasnak, I. V., Prydatko, O. V., Havryliuk, A. F., Kolesnikova, A. V., \& Hanhur, Yu. V. (2016). Analiz chynnykiv vplyvu na tryvalist sliduvannia pozhezhnoho avtomobilia do mistsia vyklyku. Scientific Bulletin of UNFU, 26(1), 286-291. [In Ukrainian].

Pasnak, I., Prydatko, O., \& Gavrilyk, A. (2016). Development of algorithms for efficient management of fire rescue units. EasternEuropean Journal of Enterprise Technologies, 3(3), 22-28. https://doi.org/10.15587/1729-4061.2016.71604

Rodrigues, E. E., Rodrigues, J. P., \& da Silva Filho, L. C. (2017). Comparative study of building fire safety regulations in different Brazilian states. Journal of Building Engineering, 10, 102-108. https://doi.org/10.1016/i.jobe.2017.03.001

Yuan, L., Thomas, R. A., Rowland, J. H., \& Zhou, L. (2018). Early fire detection for underground diesel fuel storage areas. Process safety and environmental protection, 119, 69-74. https://doi.org/10.1016/j.psep.2018.07.022

Zhang, C. (2018). Analysis of Fire Safety System for Storage Enterprises of Dangerous Chemicals. Procedia engineering, 211, 986995. https://doi.org/10.1016/j.proeng.2017.12.101

Zhang, H. Y., \& Huang, J. H. (2013). The Fire Safety Research on the Tobacco Storage. Procedia Engineering, 52, 578-582. https://doi.org/10.1016/j.proeng.2013.02.188

Zhang, Y., Zhang, M. G., \& Qian, C. J. (2018). System dynamics analysis for petrochemical enterprise fire safety system. Procedia engineering, 211, 1034-1042. https://doi.org/10.1016/j.proeng.2017.12.107

E. M. Hulida', O. M. Koval' ${ }^{2}$ I. V. Pasnak 1 , V. V. Sharyi ${ }^{1}$
${ }^{2}$ Lviv State University of Life Safety, Lviv, Ukraine
${ }^{2}$ LLC Kompaniya "Vsesvit Komfortu" Lviv, Ukraine

\section{ANALYSIS OF THE MODERN STATE OF PROVIDING FIRE SAFETY IN INDUSTRIAL}

BUILDINGS AND STORAGES

The purpose of the work is to analyze the current state of fire safety in industrial enterprises, where the risk of fires is rather high. The article contains analysis of publications in the field of providing fire safety in industrial buildings and storages that were published in the scientific metric database SCOPUS in the last five years. The actual task in the field of fire safety is the introduction of perspective directions of development of fire protection systems for industrial buildings and storages. This implementation should be based on a thorough analysis of global experience in this area. Industrial and warehouse buildings are characterized by a large amount of combustible materials and the rapid spread of the flame. Therefore, it is necessary to improve fire protection systems to protect these buildings from fire. In addition, industrial enterprises must provide internal and external fire water supply in the form of internal fire crane, fire hydrants or fire reservoirs. The study presents the influence of the duration of free fire development and the linear velocity of flame spreading on the fire area. The article describes analysis of the false alarms of fire protection system in Germany and other countries. Consequently, high-sensitivity elements in fire detectors make it possible to identify fires at an early stage, but it also makes them sensitive to false alarms. The study gives the scheme of the fire protection system of the petrochemical industry enterprises. Moreover, the article contains analysis of providing fire safety in the underground storage of diesel fuel, in the storages of hazardous chemicals, of textile industry and of tobacco. As a result, the article gives a conclusion that organization of the fire protection system in industrial buildings and storages must include the application of modern methods of fire detection and the perfection of the regulatory base. The second conclusion is the provision of fire safety of enterprises based on the effective functioning of fire protection systems, as well as the principles of early detection of fires by modern fire alarm systems.

Keywords: industrial enterprise; fire safety; fire protection systems; fire prevention; prospects of development. 